\title{
StreamStats for South Carolina: A Multipurpose Water-Resources Web Application
}

The U.S. Geological Survey (USGS) developed the South Carolina StreamStats application in cooperation with the South Carolina Department of Transportation. StreamStats (https://water.usgs.gov/osw/streamstats/) is a map-based web application that provides analytical tools useful for water-resources planning and management and many engineering purposes (Ries and others, 2017). The web application delineates drainage areas at user-selected sites on South Carolina streams, generates basin characteristics, and, where appropriate, estimates peak-flow statistics for the selected sites. StreamStats users also can obtain published flow statistics for USGS streamgages, such as peak flow, low flow, and daily mean flow durations.

\section{Use of Lidar}

From 2007 to 2013, light detection and ranging (lidar) data were collected by fixed-wing aircraft for each county in South Carolina, resulting in base elevation and derived hydrography datasets (South Carolina Department of Natural Resources, 2012) that provide the best elevation and streamflow data available for the South Carolina StreamStats application. Lidar is a remote sensing method that uses light in the form of a pulsed laser to measure variable distances to the Earth (National Oceanic and Atmospheric Administration, 2018). These light pulses provide precise, three-dimensional locational and elevation data ( $\mathrm{x}, \mathrm{y}, \mathrm{z}$ coordinates), which can be used to determine the shape and surface characteristics of the Earth. North and South Carolina are the first States to have statewide lidar-derived elevation data in the StreamStats application. In addition, the South Carolina StreamStats application uses lidar-derived streamlines, which are at the same scale as the elevation data, to ensure spatial alignment of the data.

\section{Data Processing}

The bulk of the project tasks encompassed processing the lidar-derived elevation and streamline data by using a geographic information system (GIS). Processing began with preexisting terrain datasets available from the South Carolina Department of Natural Resources. The terrain datasets were created from the bare-earth elevation measurements from lidar point cloud data and a streamline data layer that was horizontally and vertically integrated with the lidar point cloud data. Digital elevation models (DEMs) were derived from the terrain datasets as 30 -foot resolution raster grids. Some of the original data were found to have an incorrect vertical datum. To ensure proper basin delineation and spatial accuracy, the incorrect datum was corrected by applying a shift. The DEMs were further processed by "burning" streamlines into the elevation surface and filling sinks or depressions to programmatically force water downhill. Burning essentially forces the DEMs to match the locations of the streams and removes any objects (for example, bridges) at the points where streams pass through. The result of this process was the creation of flow direction and flow accumulation rasters with increased accuracy for the delineation of basins (fig. 1).
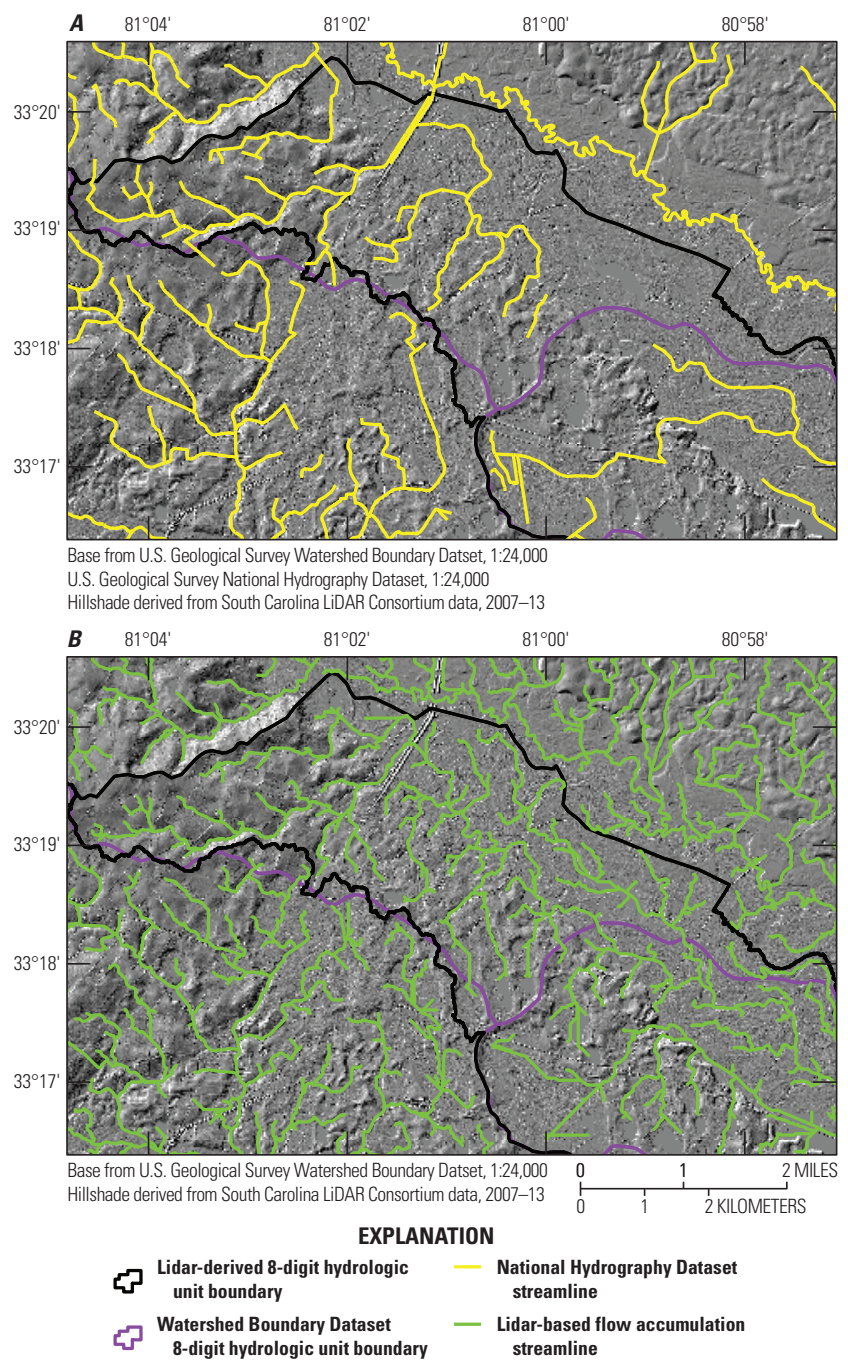

Figure 1. Examples of $(A)$ National Hydrography Dataset streamlines and $(B)$ light detection and ranging (lidar)-derived flow accumulation streamlines. The difference in area between the lidar-derived and Watershed Boundary Dataset hydrologic units shown is approximately 10 square miles. 
Streamline data were derived from the lidar data by using intensity images and photogrammetry. The streamline data were used in the DEM processing to ensure that the flow direction and flow accumulation rasters matched the streamlines. Although the streamlines are highly accurate, they could be derived by automation only where there was standing water. Therefore, in some areas, the dataset is not as complete as the National Hydrography Dataset (NHD), and in other areas, it is far denser (fig. 2).

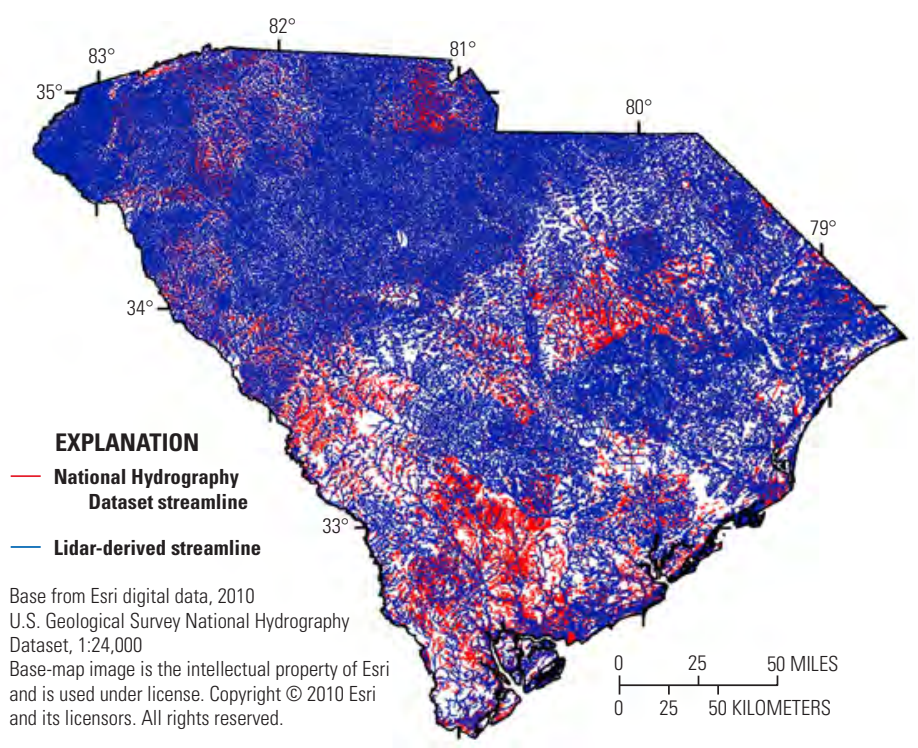

Figure 2. Light detection and ranging (lidar)-derived streamline coverage and National Hydrography Dataset coverage in South Carolina. Red lines show areas where the NHD is denser than the lidar coverage. Flow accumulation streamlines (fig. $1 B$ ) filled in these areas by adding to the lidar streamlines and continuing up stream channels.

Additionally, new hydrologic unit code (HUC) boundaries at the 8-digit level were generated on the basis of the lidar data derivatives. The lidar-based HUCs were used instead of 8-digit Watershed Boundary Dataset (WBD) HUCs because the elevation and streamlines produced from the lidar derivatives are more accurate (fig. 1B). When funding allows, the lidar-based HUCs will be incorporated in a future update of the WBD.

\section{Application Functionality}

Functionality in the current (2018) South Carolina StreamStats application includes the following:

- View an interactive map with a choice of base-map layers such as topography, political boundaries, roads, and aerial imagery (fig. 3).

- Zoom in or out to areas of interest by (1) searching for a place of interest (for example, USGS station identification number, zip code, or address), (2) choosing latitude and longitude coordinates, or (3) manually panning and setting the zoom level on a target. Click "Help" under the search box for additional search strings (fig. 3).

- Access published peak-flow frequency and other streamflow statistics, basin characteristics, and the USGS National Water Information System (NWIS) (fig. 4).
- Delineate and edit the watershed boundary for a userselected site on any stream (fig. 5).

- Compute basin characteristics, such as drainage area, percentage of impervious area, mean basin elevation, and mean annual precipitation, for a user-selected site along a stream and output results to a table and Portable Document Format file (fig. 6).

- Estimate rural and urban peak-flow frequency statistics at ungaged locations (Feaster and others, 2009, 2014) (fig. 7).

- Download the watershed boundary and basin characteristics as a geographic-oriented JavaScript Object Notation (GeoJSON) file, shapefile, or Environmental Systems Research Institute, Inc. (Esri) file geodatabase for use in a GIS.

- Obtain an elevation profile by clicking on two or more points.

- View additional South Carolina-specific layers, including bridge locations used in various scour reports and indirect flood-measurement locations.

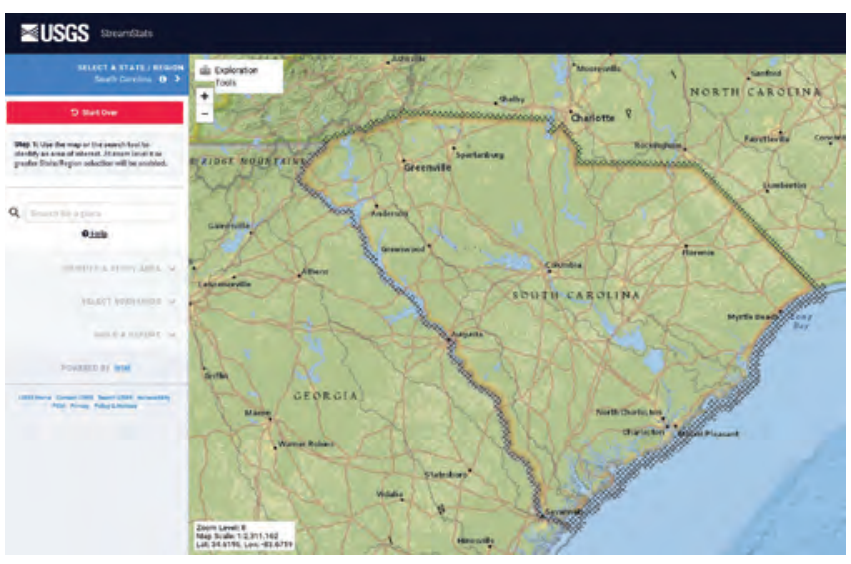

Figure 3. StreamStats user interface.

\section{Streamflow Statistics for Ungaged Sites}

The South Carolina StreamStats application (https://water.usgs.gov/osw/streamstats/) can be used to estimate peak flows for the 50-, 20-, 10-, 4-, 2-, 1-, 0.5-, and 0.2-percent annual exceedance probability (AEP) flows at rural and urban ungaged, unregulated (at high flows), and nontidal stream locations in South Carolina (Feaster and others, 2009, 2014). The AEP flows have traditionally been known as the 2-, 5-, 10-, 25-, 50-, 100-, and 500-year recurrence interval flows, respectively. The AEP conveys the probability, or odds, that a flood of a given magnitude will be equaled or exceeded in any given year. For example, a 1-percent AEP (traditionally known as the "100-year flood") corresponds to a flood that has a probability of 0.01 (or a 1-percent chance) of being equaled or exceeded in any given year.

StreamStats generates the AEP peak-flow estimates using regional regression equations developed by the USGS. The regional regression equations are functions of basin characteristics such as drainage area, percentage of the drainage area in each defined hydrologic region, and percentage of impervious area. Obtaining the basin characteristics and generating the peak-flow statistics for ungaged locations in South Carolina is accomplished by using the following steps: 
1. Identify Study Area-The study area can be located by entering the decimal latitude and longitude of the location, searching for a desired location, or by zooming to the location and selecting South Carolina as the study area in the sidebar.

2. Delineate Basin-After clicking on a stream (visible when zoomed in to at least 1:24,000 scale), the delineated basin will appear in yellow on the map (fig. 5).

3. Select Scenarios - The application can compute all available basin characteristics, a selected subset, or only the characteristics needed for regional regression equations (fig. 6). Peak-flow statistics will then be estimated by using the computed basin characteristics (fig. 7).

4. Build a Report - After the basin characteristics and peak-flow statistics have been computed, StreamStats produces a report with a map of the delineated basin and the site's summary statistics (figs. 4-7).

Other methods used to determine basin area and characteristics could take days of work, whereas StreamStats completes the process in minutes.

\section{₹USGS}

StreamStats Data-Collection Station Report

\section{USGS Station Number $\quad 02147500$}

Station Name ROCKY CREEK AT GREAT FALLS, SC

Click here to link to available data on NWIS-Web for this site.

\begin{tabular}{|c|c|}
\hline \multicolumn{2}{|l|}{ Descriptive Information } \\
\hline Station Type & Streamgage, continuous record \\
\hline Location & $\begin{array}{l}\text { Lat } 34^{\circ} 33^{\prime} 55^{\prime \prime} \text { l long } 80^{\circ} 55^{\prime} 12^{\prime \prime} \text { referenced to North American Datum of } 1927 \text {, Chester County, SC, Hydrologic Unit } \\
03050103 \text {, on left bank, } 350 \mathrm{ft} \text { downstream from Turkey Branch, } 1.0 \text { mi west of Great Falls, and at mile } 1.8 \text {. }\end{array}$ \\
\hline Gage & $\begin{array}{l}\text { Data collection platform. Elevation of gage is } 297 \mathrm{ft} \text { above NGVD of 1929. Prior to 0ctober 1, } 2006 \text { at same site, at } \\
\text { datum } 2.0 \mathrm{ft} \text { lower. }\end{array}$ \\
\hline \multicolumn{2}{|l|}{ Regulation and Diversions } \\
\hline Regulated? & False \\
\hline \multicolumn{2}{|l|}{ Period of Record } \\
\hline \multicolumn{2}{|l|}{ Remarks } \\
\hline Latitude (degrees NAD83) & 34.56542 \\
\hline Longitude (degrees NAD83) & -80.91980246 \\
\hline Hydrologic unit code & 03050103 \\
\hline County & 023-Chester \\
\hline HCDN2009 & No \\
\hline
\end{tabular}

Figure 4. StreamStats data-collection station report.

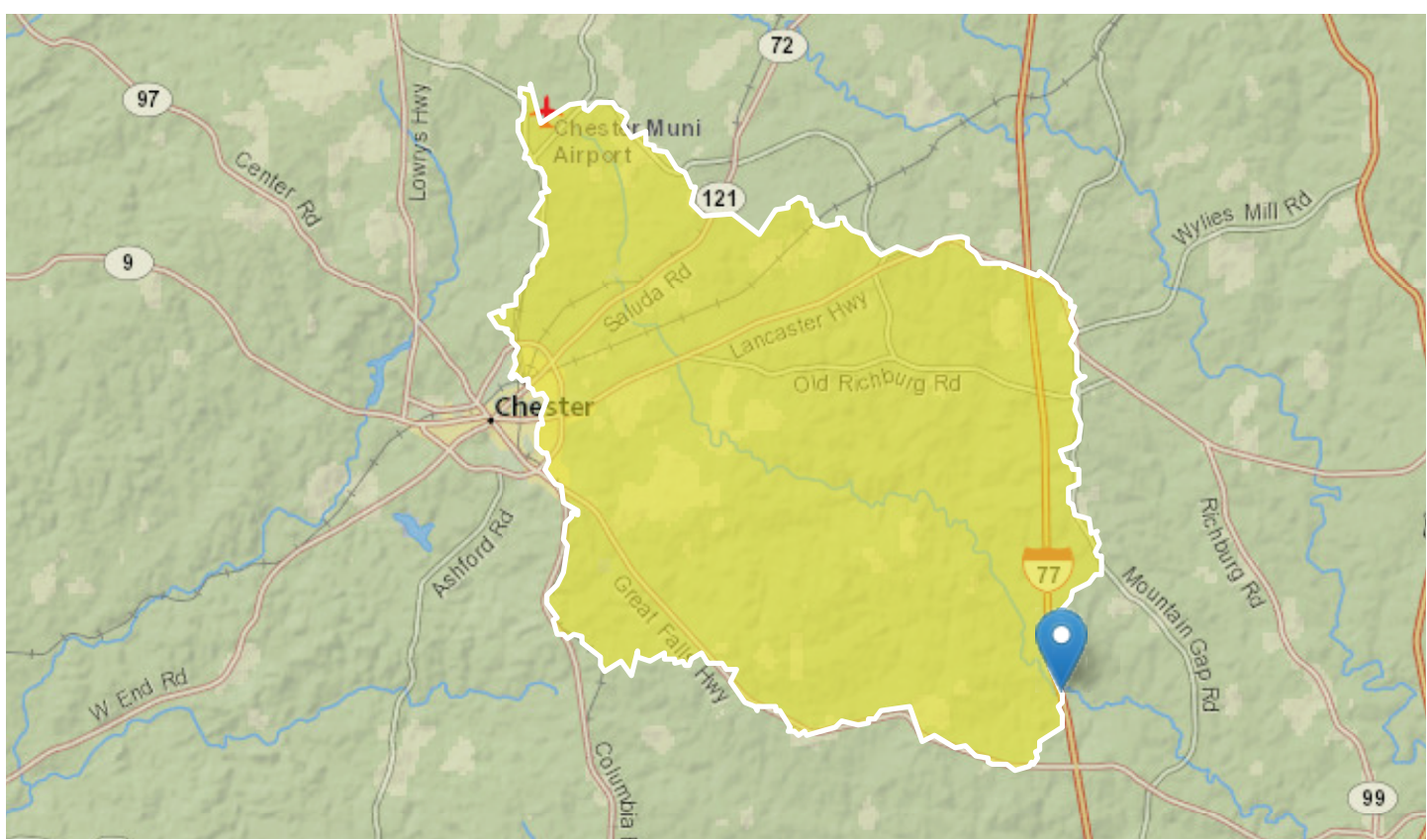

Figure 5. Example of a basin delineated at an ungaged location. 


\begin{tabular}{|llll|}
\hline Basin Characteristics & & Value & Unit \\
\hline Parameter Code & Parameter Description & 95 & square miles \\
\hline DRNAREA & Area that drains to a point on a stream & 1.95 & percent \\
\hline LC06IMP & Percentage of impervious area determined from NLCD 2006 impervious dataset & 100 & percent \\
\hline PCTREG1 & Percentage of drainage area located in Region 1 & 0 & percent \\
\hline PCTREG2 & Percentage of drainage area located in Region 2 & 0 & percent \\
\hline PCTREG3 & Percentage of drainage area located in Region 3 & 0 & percent \\
\hline PCTREG4 & Percentage of drainage area located in Region 4 & 63.553 & percent \\
\hline LC06FOREST & Percentage of forest from NLCD 2006 classes 41-43 & 44.6 & inches \\
\hline PRECIP & Mean Annual Precipitation & 526 & feet \\
\hline ELEV & Mean Basin Elevation & &
\end{tabular}

Figure 6. Example of basin characteristics determined at an ungaged location.

\begin{tabular}{|c|c|c|c|c|c|c|}
\hline \multicolumn{7}{|c|}{ Peak-Flow Statistics Parameters [Peak Southeast US over 1 sqmi 20095156] } \\
\hline Parameter Code & & & Value & Units & Min Limit & Max Limit \\
\hline DRNAREA & \multicolumn{2}{|c|}{ Drainage Area } & 95 & square miles & 1 & 9000 \\
\hline PCTREG1 & \multicolumn{2}{|c|}{ Percent Area in Region 1} & 100 & percent & 0 & 100 \\
\hline Parameter Code & \multicolumn{2}{|c|}{ Parameter Name } & Value & Units & Min Limit & Max Limit \\
\hline PCTREG2 & \multicolumn{2}{|c|}{ Percent Area in Region 2} & 0 & percent & 0 & 100 \\
\hline PCTREG3 & \multicolumn{2}{|c|}{ Percent Area in Region 3} & 0 & percent & 0 & 100 \\
\hline PCTREG4 & \multicolumn{2}{|c|}{ Percent Area in Region 4} & 0 & percent & 0 & 100 \\
\hline PCTREG5 & \multicolumn{2}{|c|}{ Percent Area in Region 5} & 0 & percent & 0 & 100 \\
\hline \multicolumn{7}{|c|}{ Peak-Flow Statistics Flow Report [Peak Southeast US over 1 sqmi 2009 5156] } \\
\hline \multicolumn{2}{|l|}{ Statistic } & Value & Unit & PI & Plu & SEp \\
\hline \multicolumn{2}{|l|}{2 Year Peak Flood } & 3040 & $\mathrm{ft}^{\wedge} 3 / \mathrm{s}$ & 1760 & 5280 & 34.5 \\
\hline \multicolumn{2}{|l|}{5 Year Peak Flood } & 5130 & $\mathrm{ft}^{\wedge} 3 / \mathrm{s}$ & 2980 & 8820 & 34 \\
\hline \multicolumn{2}{|l|}{10 Year Peak Flood } & 6610 & $\mathrm{ft}^{\wedge} 3 / \mathrm{s}$ & 3780 & 11600 & 35.1 \\
\hline \multicolumn{2}{|l|}{25 Year Peak Flood } & 8480 & $\mathrm{ft}^{\wedge} 3 / \mathrm{s}$ & 4690 & 15400 & 37.5 \\
\hline \multicolumn{2}{|c|}{50 Year Peak Flood } & 10200 & $\mathrm{ft}^{\wedge} 3 / \mathrm{s}$ & 5440 & 19000 & 39.6 \\
\hline \multicolumn{2}{|c|}{100 Year Peak Flood } & 11600 & $\mathrm{ft}^{\wedge} 3 / \mathrm{s}$ & 6010 & 22400 & 41.9 \\
\hline \multicolumn{2}{|c|}{200 Year Peak Flood } & 13000 & $\mathrm{ft}^{\wedge} 3 / \mathrm{s}$ & 6510 & 26100 & 44.3 \\
\hline \multicolumn{2}{|c|}{500 Year Peak Flood } & 15200 & $\mathrm{ft}^{\wedge} 3 / \mathrm{s}$ & 7260 & 32000 & 47.7 \\
\hline \multicolumn{7}{|c|}{ Peak-Flow Statistics Citations } \\
\hline \multicolumn{7}{|c|}{$\begin{array}{l}\text { Feaster, T.D., Gotvald, A.J., and Weaver, J.C.,2009, Magnitude and Frequency of Rural Floods in the Southeastern United States, 2006: } \\
\text { Volume 3, South Carolina: U.S. Geological Survey Scientific Investigations Report 2009-5156, } 226 \text { p. (http://pubs. usgs.gov/sir/2009/5156/) }\end{array}$} \\
\hline
\end{tabular}

Figure 7. Example of peak-flow statistics estimated at an ungaged location.

\section{Limitations}

StreamStats provides estimates of streamflow statistics at USGS streamgages obtained from published reports along with tools to estimate peak-flow statistics at ungaged locations. Users should be familiar with the assumptions and data used to develop these estimates, which are detailed in the citations provided for the various estimates.

Estimates of the peak-flow statistics at ungaged locations are based on regional regression equations documented in Feaster and others $(2009,2014)$. The methods used for those estimates are not appropriate for sites where the peak-flow magnitudes are substantially affected by regulation from impoundments, channelization, levees, or other manmade structures. The methods also do not apply where flooding is substantially influenced by extreme ocean storm surge or tidal events.

The regional regression equations used in StreamStats were developed using a specific range of basin characteristics, as documented by Feaster and others $(2009,2014)$. If StreamStats is used to obtain streamflow statistics for locations with basin characteristics outside of the specified ranges, StreamStats will warn the user that extrapolation has occurred. In such cases, the user should be aware that the uncertainty in those estimates is unknown and should not assume that the streamflow statistics are accurate. 


\section{Exploration Tools}

The Exploration Tools menu (fig. 8) provides several useful tools. The Measure tool computes the distance between two userselected points. The Elevation Profile tool produces a plot of the elevation profile between selected points on the map and generates a table of latitude, longitude, elevation, and distance at various locations across the profile. The Flow Path tool allows the user to select any point on the map and traces the path that a raindrop falling at that location would take to enter a stream and reach the outlet at the Atlantic Ocean. The Network Path tool traces the flow paths from two user-selected points until a common streamline is found. If no common streamline is found, the tool traces both paths until the network ends. The Network Trace tool allows a user to trace upstream or downstream from a selected point to find network-linked data such as streamgages or flowlines.

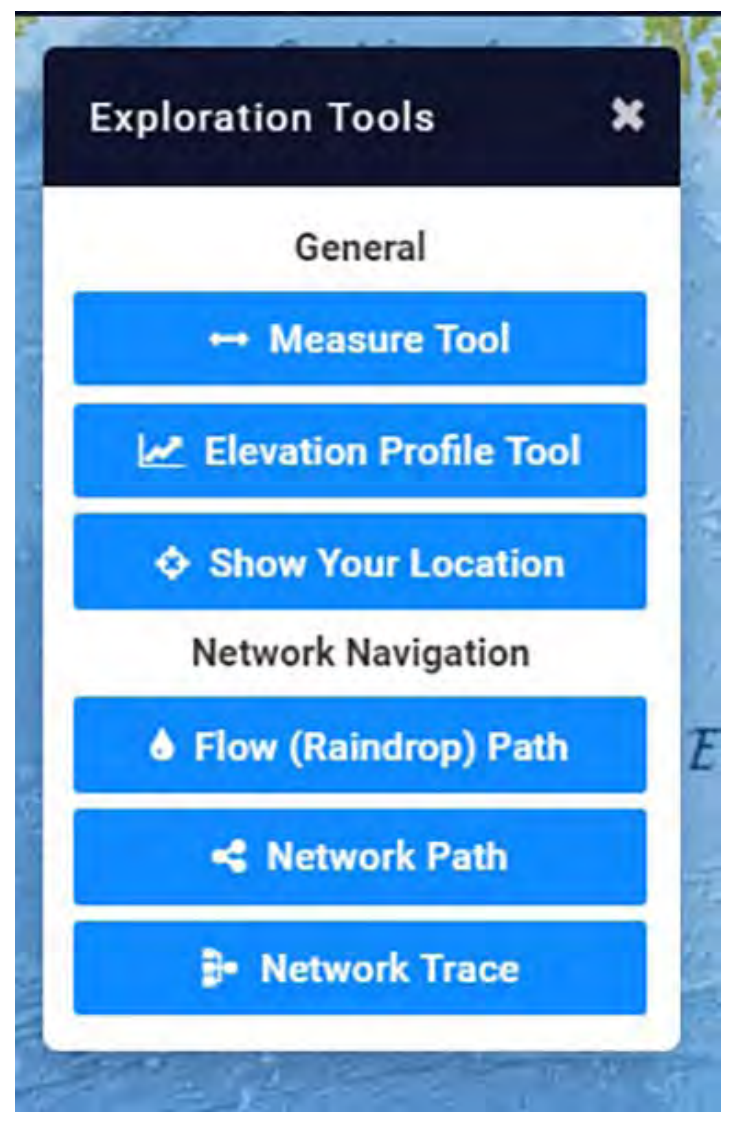

Figure 8. StreamStats Exploration Tools menu.

\section{Future Work}

Future additions to the South Carolina StreamStats application could include an upstream regulation identification tool, water-use withdrawal and discharge locations, dam locations, and unit hydrograph and rational methods for additional statistics. Other basin characteristics such as percentage of agriculture land use and basin population density also could be developed and added to the application. These and other improvements can increase efficiency by providing more functionality, placing the necessary information in the hands of users, and streamlining hydrology-related tasks. A complete list of current (2018) basin characteristic possibilities is available at https://streamstatsags.cr.usgs.gov/ss_defs/basin_char_defs.aspx (U.S. Geological Survey, 2017). Users interested in additional functionality, basin characteristics, or data layers can contact the USGS to discuss potential solutions.

\section{References Cited}

Feaster, T.D., Gotvald, A.J., and Weaver, J.C., 2009, Magnitude and frequency of rural floods in the southeastern United States, 2006-Volume 3, South Carolina: U.S. Geological Survey Scientific Investigations Report 2009-5156, 226 p., accessed February 27, 2018, at http://pubs.usgs.gov/sir/2009/5156/.

Feaster, T.D., Gotvald, A.J., and Weaver, J.C., 2014, Methods for estimating the magnitude and frequency of floods for urban and small, rural streams in Georgia, South Carolina, and North Carolina, 2011 (ver. 1.1, March 2014): U.S. Geological Survey Scientific Investigations Report 2014-5030, 104 p., accessed February 27, 2018, at https://doi.org/10.3133/ $\operatorname{sir} 20145030$.

National Oceanic and Atmospheric Administration, 2018, What is LIDAR?: National Oceanic and Atmospheric Administration web page, accessed January 24, 2018, at https://oceanservice.noaa.gov/facts/lidar.html.

Ries, K.G., III, Newson, J.K., Smith, M.J., Guthrie, J.D., Steeves, P.A., Haluska, T.L., Kolb, K.R., Thompson, R.F., Santoro, R.D., and Vraga, H.W., 2017, StreamStats, version 4: U.S. Geological Survey Fact Sheet 2017-3046, 4 p., accessed February 27, 2018, at https://doi.org/10.3133/fs20173046. [Supersedes U.S. Geological Survey Fact Sheet 2008-3067.]

South Carolina Department of Natural Resources, 2012, LiDAR and related data products: South Carolina Department of Natural Resources web page, accessed June 11, 2012, at http://www.dnr.sc.gov/GIS/lidar.html.

U.S. Geological Survey, 2017, Basin characteristic definitions: U.S. Geological Survey StreamStats web page, accessed October 2017, at https://streamstatsags.cr.usgs.gov/ss_defs/ basin_char_defs.aspx.

For further information, please contact

Director, South Atlantic Water Science Center

U.S. Geological Survey

720 Gracern Road, Suite 129

Columbia, SC 29210

(803) $750-6100$

https://www.usgs.gov/centers/sa-water

Visit the USGS office of Surface Water StreamStats Program homepage at https://water.usgs.gov/osw/streamstats/. 